\title{
Article
}

\section{Current and historical involvement of dentistry in child protection and a glimpse of the future.}

Park, CM and Welbury, Richard

Available at http://clok.uclan.ac.uk/16196/

Park, CM and Welbury, Richard ORCID: 0000-0002-9322-2440 (2016) Current and historical involvement of dentistry in child protection and a glimpse of the future. Oral Diseases, 22 (7). pp. 605-608. ISSN 1354-523X

It is advisable to refer to the publisher's version if you intend to cite from the work. http://dx.doi.org/10.1111/odi.12485

For more information about UCLan's research in this area go to http://www.uclan.ac.uk/researchgroups/ and search for < name of research Group>.

For information about Research generally at UCLan please go to http://www.uclan.ac.uk/research/

All outputs in CLoK are protected by Intellectual Property Rights law, including Copyright law. Copyright, IPR and Moral Rights for the works on this site are retained by the individual authors and/or other copyright owners. Terms and conditions for use of this material are defined in the policies page. 
Title:

Current and Historical Involvement of the Dentistry in Child Protection and a Glimpse of the Future Running Title:

A Brief Review of Child Protection in Dentistry

Authors:

Mrs Christine M Park

University of Glasgow Dental Hospital \& School

Prof Richard Welbury

University of Central Lancashire

\section{Corresponding Author:}

Mrs Christine M Park

Paediatric dental Dept,

Glasgow Dental Hospital \& School

378, Sauchiehall Street,

Glasgow

G2 3JZ

01412119666

Christine.park@glasgow.ac.uk 


\title{
Current and Historical Involvement of the Dentistry in Child Protection and a Glimpse of the Future
}

\begin{abstract}
Dental teams have been involved with child protection for over forty years. This brief review summarises their involvement in the detection of various types of child abuse and goes on to discuss the gap between the proportions of dental professionals who suspect child abuse or neglect in their paediatric patients and those who refer such cases on. Potential reasons for this discrepancy are discussed and a glimpse of the future is given as to where further research may be necessary to tackle this existing gap.
\end{abstract}

\section{Introduction}

When a dental team has concerns about a child's wellbeing the situations can be complex. Understanding the thoughts, feeling, motivations, inhibitory factors and decision making processes involved is essential in helping to resolve situations. There are a number of potential reasons that affect referral: concerns relating to impact on the practice, fear of violence to the child, fear of violence to the GDP, fear of litigation, fear of consequences to the child from statutory agencies, lack of knowledge of referral procedures and lack of certainty of the diagnosis. However we don't fully understand which reasons are most important or crucial in the decision to report or not. This review will explore this history of the dental teams' involvement in child protection and safeguarding as well as explaining the current responsibilities of dental teams with a glimpse into the future and how this may well change.

\section{The effect of all types of abuse /neglect}

In the United Kingdom it is reported that in 2014 some 50,000 children were identified as needing protection from abuse or neglect and it is estimated that 1 in 10 children in the UK experience neglect (NSPCC 2015). Statistics and numbers are difficult to interpret as official statistics only identify those who have been identified as needing protection or support. The NSPCC estimate that for every child identified as needing protection there are another 8 who are suffering (Jütte et al., 2015). Children who are abused or neglected don't always have the ability to ask for help themselves. They may be too young, scared or ashamed to report what is happening to them and many may not realise that what they are experiencing is not normal. Social and cognitive development of children as well as their physical and emotional health is damaged in the short term. However in the long term damage persists and adults who were neglected as children have higher rates of arrest, suicide and major depression as well as health issues such as diabetes and heart disease.

\section{Historical aspects of child protection and dentistry}

The involvement of the dental profession with child protection and safeguarding began to be reported in the scientific literature in the 1960s and 1970s, not long after the landmark paper by C. Henry Kempe in 1962, "The battered child syndrome". This paper described this as a clinical condition which should be considered in any child with "evidence of fracture of any bone, subdural haematoma, failure to thrive, soft tissue swellings or skin bruising, in any child who dies suddenly, or where the degree and type of injury is at variance with the history given" (Kempe et al., 1962). Since then much has been published about the involvement of the dental profession in identifying and reporting cases of child abuse and neglect. This has coincided with changing global attitudes towards the treatment of children. Previously parents were left to decide how they would treat and discipline 
their children and it was unlikely that anyone (general public, health or state) would intervene. This began to change in 1874 in New York State with the case of Mary Ellen (Schwartz and Woolridge, 1982). She was chronically abused by her guardians but in the absence of any laws to protect children her case was brought to court by The American Society for the Prevention of Cruelty to Animals, on the basis that Mary Ellen was a member of the animal kingdom. This lead to the formation of the New York Society for the Prevention of Cruelty to Children in 1875. The United Kingdom Society for the Prevention of Cruelty to Children was founded in 1884.

The medical professions' involvement in child abuse and child protection began with radiologist John Caffey in 1946 (Caffey, 1946), where he observed that children with subdural haematomas sometimes showed changes in their long bones which were suggestive of previous trauma, and culminated in Kempe's landmark paper of 1962 (Kempe, 1962). Subsequently laws were passed in all states in the USA which required mandatory reporting of suspected cases of child abuse by health professionals (including dentists).

From the 1970's onwards there have been publications in the dental literature surrounding the dentists' role in child protection and the identification of child abuse. Early papers concentrated on the physical abuse of children and it is now recognised that $50-75 \%$ of physically abused children have orofacial signs of abuse which would be obvious to a dental practitioner (Becker et al., 1978; Malecz, 1979; da Fonseca et al., 1992; Jessee, 1995; Cairns et al., 2005a). Orofacial signs of physical child abuse include bruising of soft tissues (especially those that do not overlie a bony contour), abrasions, multiple injuries, bruising of different vintages, scarring of the lips, dento-alveolar injuries, fractures, burns and "tattoo" injuries which reflect the shape of the offending object. It is the history as well as the site of the injury which may distinguish them from accidental injuries. If the explanation for the injury does not fit with the clinical picture then the dental team should have a high index of suspicion. Accidental injuries commonly involve bony prominences and should be in keeping with the development of the child, whereas injuries to soft tissues or injuries that would be unusual for the child's developmental stage are suspicious.

Dental teams may see the signs of physical abuse but they are critical to the recognition of neglect and specifically dental neglect (Harris et al., 2006; Harris et al., 2009a; Balmer et al., 2010). Neglect is defined as "the persistent failure to meet a child's basic physical and/ or psychological needs, likely to result in the serious impairment of the child's health or development" and it remains the most common form of child abuse in the UK (HM Government, 2010; Jütte et al., 2015). The UK's first dental guideline about child protection (Harris et al., 2006) and the British Society of Paediatric Dentistry (Harris et al., 2009a) define dental neglect as "the persistent failure to meet a child's basic oral health needs, likely to result in the serious impairment of a child's oral or general health or development." The use of "persistent" rather than "wilful" makes this definition more inclusive than the American definition (American Academy of Pediatric Dentistry, 2005).

Dental teams may also see children who have been sexually abused. Recorded sexual offences against children in the UK have increased over the past year as have contacts regarding sexual sexual abuse to both the NSPCC and ChildLine helplines (Jütte et al., 2015). The general features that the dental team should be aware of are the oral manifestations of sexually transmitted infections and what tests may be required. Some of these manifestations may not be particular to sexual abuse. Sudden changes in eating and sleeping patterns, becoming withdrawn, nightmares, being fearful of adults not previously feared, precocious sexual interest, self-harm and low esteem are also recognised as sequelae of child sexual abuse and an alert for referral to medical colleagues (Casamassimo, 1986). The National Collaborating Centre for Women's and Children's Health reminds dentists that if they discover that any of their child patients aged 13 years or younger are 
pregnant this may also be a sign of child maltreatment and they should share their concerns (National Collaborating Centre for Women's and Children's Health, 2009).

Emotional abuse is now recognised as a component in all categories of abuse (HM Government, 2010; Jütte et al., 2015). Signs and symptoms of emotional abuse may be noticed by dentists and include babies who are demanding / clingy or irritable, and who may also have feeding difficulties and cry a lot. In school aged children there may be developmental delay, soiling or wetting problems, poor behaviour, and non-attendance at school or rejection by their peers. Teenagers who have suffered emotional abuse may exhibit problems with drugs / alcohol, behavioural problems, self-harming, eating disorders or depression (HM Government, 2010).

Kempe's original formula for assessing those at risk of child abuse included: something wrong with the parents; something wrong with the marriage; something wrong with the child; life stresses; and parents who have no access to lifelines. Parental factors which may increase the risk of child abuse include: young parents of low intelligence (who have often been abused themselves); mother divorced/single cohabiting with person responsible for the violence; disability; criminal record; and emotional immaturity (Kempe et al., 1962). Drugs, alcohol, poverty, social isolation, unemployment and marital stress may all contribute (HM Government, 2010). Where the child is concerned, crying, soiling, disability and failed expectations may be contributing factors. Additionally premature babies and those that are the result of an unwanted pregnancy may be at higher risk of abuse (Kempe et al., 1962; HM Government, 2010). Disabled children are also 3.4 times more likely to have been maltreated than their non-disabled peers (Sullivan and Knutson, 2000 ) and are judged more vulnerable because they experience greater physical and social isolation, a lack of control over their life and bodies, greater dependency on others, and problems in communication(Wescott and Jones, 1999).

\section{The gap between those who suspect and those who refer}

Nationally and internationally there is recognised to be a gap between the numbers of dental professionals who have suspect child abuse/ neglect and those who actually refer cases (Saxe and McCourt, 1991, Kilpatrick et al., 1999, Cairns et al 2005, Harris et al., 2009b, Uldum et al 2010, Harris et al., 2013). Previous to 2003 it was unknown whether general dental practitioners (GDPs) in the UK accepted they had a role in child protection or if they felt they had needs in developing their role further (Welbury et al., 2003). The authors discussed and presented their findings under three main headings namely GDP relevant background factors, perceptions and behaviours in child protection issues and inhibiting and motivating factors in child protection.

The GDP relevant background issues included isolationism, lack of holistic approach to patient care and attitudes to further training and professional development. The theme of isolationism meant that GDPs lacked experience and confidence in acting in a multi-professional context. The theme of a lack of a holistic approach to patient care meant that GDPs mainly focus on clinical signs and symptoms but are less confident in a holistic approach to child health. The last of the GDP relevant background issues discussed was attitudes to further training and professional development. This was affected by time and financial pressures as well as there being a low level of external requirements to gain the knowledge. The external requirements issue is interesting to highlight as the paper suggests that the external professional environment affects choices when it comes to further training and professional development. In April 2015 safeguarding of children did become a recommended continued professional development (CPD) topic from the General Dental Council for dental professionals but is still not highly recommended or mandatory. 
Perceptions and behaviour in child protection covered perception of child protection issues. This appeared to be largely influenced by the media and led to a hesitancy of the GDPs to get involved. The behaviours explored included: who had actually had concerns and acted on them and who had had worries but had taken no action. This demonstrated that there was a gap between those who had suspected and those who had acted. If participants had not had any previous experience of child protection concerns they anticipated that they would have a variety of potential outcomes of interaction including: avoiding it; discussing it with colleagues in their practice; getting a second opinion from colleagues; discussing it with a specialist in paediatric dentistry or consulting the child's general medical practitioner. Additionally when it came to behaviours in note keeping the details recorded were in relation to oro-facial details and nothing on any wider concerns.

The theme of inhibiting and motivating factors in child protection identified that all the participants in the focus groups acknowledged they have an ethical responsibility as professionals and members of society to protect children. However there were various inhibiting factors identified including: difficulty identifying abuse; concern about the outcome (making things worse, getting it wrong, consequences for themselves and their practice, anticipated antagonism from parents) and a perceived need for certainty before action. The uncertainty related not only to difficulties and complexities in identification but also to poor knowledge of referral routes and procedures. It was noted that coping with uncertainty contrasts with the GDPs routine clinical practice where they are accustomed to feeling confident in identifying signs and symptoms. The paper suggested some facilitators including: frequent communication with practice staff both formally and informally; establishing links and contacts with other dentists, general medical practitioners and other professionals; development of interaction skills with children and families; informal professional advice; local support; feedback systems involving dentists; raising awareness of the issue; undergraduate and postgraduate training; wider promotion of courses and circulation of guidelines.

Since the 2003 paper there have been 2 papers in Scotland looking at the role of general dental practitioners in child abuse (Cairns et al. 2005, Harris et al. 2013). Both these papers are based on questionnaires sent out to a proportion of general dental practitioners in Scotland and thus attempted to quantify the proportions of dentists on Scotland who had expected abuse or neglect and those who had referred cases as well as find out what proportions of GDPs picked suggested responses as their reasons for not referring. Both demonstrated that the gap between those who suspect and refer was still apparent, although in the 2013 paper there was a larger proportion of dentists for both those who suspected (37\%) and who referred (11\%) than in the 2005 paper $(29 \%$ and $8 \%$ respectively). This perhaps reflected an increasing awareness of the problem. Additionally in 2013 a larger proportion of dentists had had undergraduate (29\%) and postgraduate (55\%) training. However despite this likely increased awareness and an increase in training uptake it is clear that efforts so far have not tackled the gap. The suggested factors which influenced the decision to refer were: concerns of impact on the practice; fear of violence to the child; fear of violence to the GDP; fear of litigation; fear of consequences to the child from statutory agencies; lack of knowledge of referral procedures; and lack of certainty of the diagnosis. In summary the two main issues appear to be fear (of potential outcomes) and confidence (in how to refer and lack of confidence in suspecting a diagnosis).

Kvist and colleagues attempted to examine what factors cause specialists in paediatric dentistry to suspect child abuse or neglect and aimed to determine what influenced their decisions to report (Kvist et al. 2014). They again used focus groups with group sizes ranging from 2 to 6 people in a total of 4 focus groups. The main theme they elicited was "the dilemma of reporting child maltreatment" with three subthemes of "to support or report", "differentiating concern for well- 
being form maltreatment" and the "supporting or unhelpful consultation" with colleagues or other health professionals. The consultation with colleagues was regarding a need for reassurance that the concern the specialist had was adequate for a referral. This shows parallels with the general dental practitioners need for certainty of the diagnoses and suggests that the decision to report is not always easy even for those who are widely regarded as experts in paediatric dentistry.

\section{A glimpse of the future}

The major concern now is that despite at least 40 years of recognition that dental teams can play a significant role in protecting children there remains a gap between the number of dental professionals who suspect abuse or neglect in a paediatric patient and those who actually refer suspected cases onto appropriate authorities. Although potential barriers to referral have been identified and targeted in training courses the gap between suspicion and referral has not really seemed to change. This suggests that the full complexity of the problem has not yet been illuminated. Dental teams however are not the only health professionals for whom a gap between suspicion and referral has been identified. 


\section{$\underline{\text { References }}$}

American Academy of Pediatric Dentistry (2005). Guideline on oral and dental aspects of child abuse and neglect. Pediatr Dent 27: 64-67.

Balmer R, Gibson E, Harris J (2010). Understanding child neglect. Current perspectives in dentistry. Prim Dent Care 17: 105-109.

Becker DB, Needleman HL, Kotelchuck M (1978). Child abuse and dentistry: orofacial trauma and its recognition by dentists. J Am Dent Assoc 97: 24-28.

Caffey J (1946). Multiple fractures in the long bones of infants suffering from chronic subdural hematoma. Am J Roentgenol Radium Ther 56: 163-173.

Cairns AM, Mok JYQ, Welbury RR (2005a). Injuries to the head, face, mouth and neck in physically abused children in a community setting. Int J Paediatr Dent. 15: 310-318.

Cairns AM, Mok JYQ, Welbury RR (2005b). The dental practitioner and child protection in Scotland. Br Dent J. 199: 517-520

Casamassimo PS (1986). Child sexual abuse and the pediatric dentist. Pediatr Dent 8: 102-106.

da Fonseca MA, Feigal RJ, ten Bensel RW (1992). Dental aspects of 1248 cases of child maltreatment on file at a major county hospital. Pediatr Dent. 14: 152-157

Harris J, Sidebotham P, Welbury R, Townsend R, Green M, Goodwin J, Franklin C (2006). Child protection and the dental team: an introduction to safeguarding children in dental practice. Sheffield: Committee of Postgraduate Dental Deans and Directors (COPDEND) UK. Available at: www.cpdt.org.uk or https://www.bda.org/childprotection

Harris JC, Balmer RC, Sidebotham PD (2009a). British Society of Paediatric Dentistry: a policy document on dental neglect in children. Int J Paediatr Dent. Available at:

http://bspd.co.uk/Portals/0/Public/Files/PolicyStatements/Dental\%20Neglect\%20In\%20Children.pdf

Harris JC, Elcock C, Sidebotham PD, Welbury RR (2009b). Safeguarding children in dentistry: I. Child protection training, experience and practice of dental professionals with an interest in paediatric dentistry. Br Dent J. 206: 409-414.

Harris CM, Welbury R, Cairns AM (2013). The Scottish dental practitioner's role in managing child abuse and neglect. Br Dent J. 214: E24 DOI:10.1038/sj.bdj.2013.435

HM Government, 2010. Working Together to Safeguard Children-A guide to inter-agency working to safeguard and promote the welfare of children. London: The Stationery Office.

Jessee SA (1999). Child abuse and neglect: implications for the dental profession. Tex Dent J. 116: 4046.

Jütte S, Bentley H, Tallis D, Mayes J, Jetha N, O'Hagan O, Brookes H, McConnell N (2015) How safe are our children? The most comprehensive overview of child protection in the UK. NSPCC. Available at: https://www.nspcc.org.uk/globalassets/documents/research-reports/how-safe-children-2015report.pdf Accessed March 2016. 
Kempe, C.H., Silverman, F.N., Steele, B.F., Droegemueller, W., Silver, H.K., 1962. The battered child syndrome. Journal of the American Medical Association 181: 17-24.

Kilpatrick NM, Scott J, Robinson S. Child protection: a survey of experience and knowledge within the dental profession of New South Wales, Australia (1999). Int J Paediatr Dent.9:153-159.

Kvist T, Wickström A, Miglis I, Dahllöf G. (2014). The dilemma of reporting suspicions of child maltreatment in pediatric dentistry. Eur J Oral Sci 122: 332-338

Malecz RE (1979). Child abuse, its relationship to pedodontics: a survey. ASDC J Dent Child 46: 193194.

National Collaborating Centre for Women's and Children's Health (2009). When to suspect child maltreatment: full guidance. Clinical Guideline 89. National Institute for Health and Clinical Excellence. Royal College of Obstetricians and Gynaecologists: London.

NSPCC (2015). Child protection register statistics UK: 2010 - 2014. Available at: https://www.nspcc.org.uk/globalassets/documents/statistics-and-information/child-protectionregister-statistics-united-kingdom.pdf

Saxe MD, McCourt JW (1991). Child abuse: a survey of ASDC members and a diagnostic-dataassessment for dentists. ASDC J Dent Child. 58: 361-366.

Schwartz S, Woolridge E (1982). Child Abuse, in: Cottone, J.A., Standish, S.M. (Eds.), Outline of Forensic Dentistry. Year Book medical Publishers Inc, pp. 128-132.

Sullivan PM, Knutson JF (2000). Maltreatment and disabilities: a population-based epidemiological study. Child Abuse Negl. 24: 1257-1273.

Uldum B, Christensen HN, Welbury R, Poulsen S (2010). Danish dentists' and dental hygienists' knowledge of and experience with suspicion of child abuse or neglect. Int J Paediatr Dent. 20:361365.

Welbury RR, MacAskill SG, Murphy JM, Evans DJ, Weightman KE, Jackson MC, Crawford MA (2003). General dental practitioners' perception of their role within child protection: a qualitative study. Eur J Paediatr Dent 4: 89-95

Westcott HL, Jones DP (1999). The abuse of disabled children. J Child Psychol Psychiatry 40: 497-506. 